\title{
The options for coordinating NGOs' efforts with other international actors: the security dimension
}

\author{
O. Khar \\ Department of Political Science and International Relations Lviv Polytechnic National University, Lviv, Ukraine \\ Corresponding author. E-mail: oksanakhar7@gmail.com
}

Paper received 04.03.20; Accepted for publication 26.03.20.

\begin{abstract}
https://doi.org/10.31174/SEND-HS2020-232VIII40-16
\end{abstract}
\begin{abstract}
The main options for coordinating non-governmental organization's efforts with other international actors in the sphere of peace and security are considered in the article. Based on the system method, the article deals with the major ways of NGOs' interacting with both international intergovernmental organizations and with individual countries in the contemporary world. The article reveals the the main areas of cooperation of INGOs with government organizations, in particular with The Organization for Security and Cooperation in Europe, The European Union, The Council of Europe and others. The article identifies that in recent years the scope of contacts between NGOs and UN specialized agencies has expanded significantly, including UNESCO, UNICEF, the United Nations Democracy Fund and the UN Security Council. The tremendous impact of NGOs on the actions and development of both governmental and intergovernmental actors is analyzed in the article.
\end{abstract}

Keywords: international non-governmental organization's, international intergovernmental organizations, peace and security, UN specialized agencies, The European Union.

In the realities of modern international relations, the states have long gone beyond only interstate communication, and the state itself has lost the role of an international actor as a monopolist in the interstate interaction. The emergence of new international actors indicates the formation of the latest trends in world politics, which are based on the formation and functioning of multifunctional interstate institutions that interact. International non-governmental organizations (INGOs) are emerging as new actors in international relations that realize the global goals of society in political, economic, legal, social, cultural and other fields and affect the dynamics of the development of the world community.

The INGOs solve their tasks at the intergovernmental level, where the international legal norms are created outside the traditional intergovernmental channels, in independently founded arenas together with other non-governmental organizations. However, INGOs can only perform their functions under one condition - interaction and cooperation with other international actors (states and international governmental organizations (IGO).

Among researchers, who paid attention to the problem of the cooperation between non-governmental organization's and other international actors in the sphere of peace and security Yu. Kozak, V. Kovalevska, A. Naumov and others should be mentioned. At the same time, notwithstanding the wide range of scholars who have paid attention to this aspect of the interaction of international actors, today there is no single integrated approach to the identifying the main ways of cooperation in conflict situations and ensuring the safety of peoples in global political experience.

Therefore, the aim of the article is to determine the main options for coordinating non-governmental organization's efforts with other international actors in the sphere of peace and security.

Within the framework of consultative relations with international intergovernmental organizations, INGOs participate in the work of all organizations and institutes of the UN system and other IGOs on almost equal rights with official delegations of countries: they propose draft treaties and conventions, participate in their discussion, providing expert, scientific, technical and other conclusions; control their compliance after adoption, etc.

Therefore, in order to achieve the global goals of humanity, INGOs are actively cooperating with IGOs, namely: the United Nations (UN), the World Bank (WB), the World Trade Organization (WTO), the International Monetary Fund (IMF), the North Atlantic Treaty Organization (NATO), The Organization for Security and Cooperation in Europe (OSCE), the European Union (EU) and many others. In cooperation with intergovernmental structures, INGOs are given exceptional opportunities on the world stage. They may, for example, make important proposals on the agenda of governmental organizations. As is well known, many human rights issues have been raised at the UN sessions on the initiative of the non-governmental sector. Very active global NGOs cooperate with the structures of intergovernmental organizations in practical work. First of all, this concerns the interaction of humanitarian non-governmental organizations with relevant UN agencies, in particular the United Nations Development Program (UNDP), the United Nations Children's Fund (UNICEF), the Office of the United Nations High Commissioner for Refugees and others [1, P.49-76].

Researchers Yu. Kozak and V. Kovalevskyi point out that the cooperation between INGOs and IGOs is carried out in the following main areas:

- provision of the information on its activities and dissemination of the information received from intergovernmental organizations;

- providing advice on matters within their competence to other organizations, community groups and individuals;

- participation in the law-making process, drafting of the international agreements;

- monitor compliance with the international law, especially in the fields of human rights and the protection of the environment;

- participation in the investigation of the violations of international law;

- setting up the investigative commissions to inquire the international crimes;

- attracting qualified experts from non-governmental organizations to gather information, clarify positions, 
which allow to rely on public opinion when making decisions [2, c. 341].

In recent years, the scope of contacts between the INGOs and the UN has expanded considerably, which is no longer limited to socio-economic issues but also political. UN structures are interested in developing relations with INGOs, as the work of UN specialized agencies in dealing with numerous issues is multifaceted. The UN General Assembly has repeatedly called on the INGOs to assist with its resolutions, to participate in certain UN activities, or to assist in resolving any issue. The United Nations Department of Global Communications is a kind of a platform for establishing UN contacts with NGOs. Today it is about 1,500 NGOs, which represent and defend civil society interests. For example, the well-known non-governmental organization Oxfam America, which mainly cooperates with the United Nations through Oxfam International, is looking for solutions to problems related to the world's poverty, hunger and social injustice issues by constantly interacting with the United Nations [3].

Within the UN system, UNESCO has the largest amount of cooperation with INGOs, since the charter of that institution states the need to involve INGOs to carry out tasks relevant to their field of activity. The options for coordinating efforts in cooperation between INGOs and UNESCO are: to hold international conferences, forums, international grants and competitions that contribute to solving global humanity problems, in particular in the security field. This cooperation can also be achieved through the participation of the INGO representatives in the work of the advisory committees set up by the UNESCO General Conference. In UNESCO, as in ECOSOR, there are certain categories of advisory status for INGOs (A, B and C). To be more precise, at present 344 non-governmental organizations maintain "official" relations with UNESCO, and almost 1200 NGOs cooperate with the organization on a one-off basis [4]. In particular, looking at the list of INGOs that cooperate with UNESCO, here are some of them:

- ASSISTANCE to the INTEGRATION of DEMOBILIZED CHILD SOLDIERS (France);

- SAVE the CHILDREN INTERNATIONAL (Great Britain);

- RELIGIONS for PEACE (USA);

- PEACE and SPORT (Monaco);

- ARAB INSTITUTE for HUMAN RIGHTS (Tunisia) [5].

It is necessary to mention about the United Nations Democracy Fund (UNDEF), which supports projects that promote the role of civil society, protect human rights, and encourage the participation of all social groups in democratic processes. UNDEF projects are for two years, with project grants ranging from $\$ 100,000$ to $\$ 300,000$ USA. The vast majority are implemented by local NGOs in Africa, Asia, Eastern Europe and Latin America, both in the transition phase and in the consolidation phase of democratization. The UNDEF also supports a number of large, regulatory and policy-oriented global and regional projects. Thus, UNDEF plays a special role in engaging with NGOs as representatives of a democratic civil society. For example, in Asia, the foundation has funded three projects that promote the democratic rights of Asian youth [6].

UNICEF also actively cooperates with NGOs in its work. In particular, UNICEF's official partners are a lot of
NGOs such as: European Network of Ombudspersons for Children (child protection); European Disability Forum (protection of people with disabilities); European Institute for Gender Equality (gender issues); European Women's Lobby (gender issues); International Association «Step by Step» (education, gender issues, early childhood development) and others [7].

UN Member States are constantly developing close contacts with NGOs. For example, on the issue of children and military conflict. The UN Special Representative facilitates direct contact between NGOs, dealing with child protection, and the UN Security Council, using the Aria formula for children and armed conflict. At this time, this formula is regularly applied in practice for the purpose of a direct exchange of views on the eve of the annual open debate in the Security Council on the protection of children in armed conflict. In our view, it is now extremely important to further deepen such interaction between UN Member States and NGOs.

The Special Representative also set up a structure for consultation with NGOs at the level of the United Nations Central Institutions on Monitoring and Reporting, as well as on all other aspects of the program of activities. This NGO Advisory Group includes the following international non-governmental organizations: «Child Soldiers»; «Observations: Children and Armed Conflict»; «Save the Children»; «Human Rights Watch»; «International Crisis Group»; «World Vision»; «The International Rescue Committee»; «Oxfam International»; «Caritas International»; «International Center for Justice in Transition»; «Children of War»; «International Movement for the Protection of Children»; «International Center for Displaced Persons Observation»; «Global Coalition for Protecting Schools from Attacks» [8].

Today, the EU is a unique player on the world stage, as it is active in the field of democracy and the promotion of human rights, using all possible and accessible methods to promote human rights, especially in the third world. This initiative is part of the European Union's long-term support for the promotion of democracy and human rights worldwide, which is provided by the EU under a number of mechanisms. One of such mechanisms is the European Instrument for Democracy and Human Rights (EIDHR). It was adopted by the European Parliament and the European Council in March 2014 for the period 2014-2020, to provide financial support to actions aimed at strengthening democracy and human rights in non-EU countries. It has replaced this instrument and builds on previous programs, namely the EIDHR 2007-2013 and the European Initiative on Democracy and Human Rights 2000-2006.

The Council of Europe, with 47 member states and a population of more than 800 million people, was founded in 1949 to ensure that the events of World War II will never happen again. The work of the Council of Europe is unique in that it is based on the values of human rights, democracy and the rule of law. It is the only organization in the world where youth leaders make decisions on youth priorities, programs and policies side by side with government representatives. Based on the goals of the Council of Europe, the European Youth Foundation (EYF) was founded in 1972, which is now based at the Strasbourg European Youth Center of the Council of Europe and plays an important role in the work of the Council of Europe, as it aims to encourage 
cooperation between young people in Europe civil society and political decision-making. For over 40 years, the EYF has provided support and funding for youth activities that promote human rights, democracy, tolerance and solidarity. Currently, the EYF is a powerful partner for all youth NGOs, as it provides young people with the opportunity to voice political and democratic life, as well as the necessary tools to function effectively in today's society [9].

The EYF provides four types of grants that are open to different types of youth NGOs. The projects should be aimed at: 1) strengthening peace and cooperation; 2) promoting closer cooperation and mutual understanding between young people; 3 ) encouraging the exchange of information; 4) promoting mutual assistance. They should also be in line with the current priorities of the Council of Europe's youth sector [10].

A recent initiative in Europe is a partnership between the Netherlands Helsinki Committee and the Council of Europe to promote the creation of a network of NGOs providing legal assistance to victims of trafficking and improving early access for victims of trafficking in human beings to legal assistance and judicial representation, as well as access to justice in general [11].

When considering how NGOs interact with other international actors, it is worth mentioning that the National Endowment for Democracy (NED) is a privately owned, nonprofit, United States-based foundation that grows and strengthens democratic institutions around the world. The NED was created in the early 1980 s, based on the idea that US assistance in efforts to promote democracy abroad would be beneficial to both the United States and those struggling for freedom and self-government worldwide. The NED annually allocates over 1600 grants to support NGO projects abroad that work for democratic ends in more than 90 countries. Grant amounts vary depending on the size and scale of the projects, but the average grant lasts 12 months and is about $\$ 50,000$. The NED only finances non-governmental organizations, which may include civil organizations, associations, independent media and other similar organizations. The Fund encourages applications from organizations working in diverse settings, including in newly created democracies, semi-authoritarian countries, extremely repressive societies and countries experiencing democratic transformations [12].

Regarding the interaction of NGOs with the governments of the countries, it is appropriate to mention the United States Agency for International Development (USAID). President John Kennedy established the United States Agency for International Development in 1961 to manage the efforts of the United States Government on international development and humanitarian action. Today, USAID staff are working in more than 100 countries with the same key goals that President Kennedy outlined 50 years ago - promoting US foreign policy interests in expanding democracy and free markets, as well as in helping people struggling to improve the quality of life, to those recovering from a natural disaster or to those seeking to live in a free and democratic country [13].
The OSCE also works closely with NGOs, for example, member-states of the OSCE have long accepted the position that OSCE institutions should cooperate with non-governmental organizations.

Thus, the Paris-based non-governmental organization Comité Contre l'Esclavage Moderne (CCEM) and the «AIRE Center» (Consultations on personal rights in Europe) provide counseling and assistance to victims of trafficking in human beings, including representing victims interests in the European Court of Human Rights or acting through third parties [14].

In response to the challenges of the current migration crisis, a network of NGOs «Missing Children Europe» has organized a free hotline in Europe (by the number 116000 in 32 European countries) and trains professionals, including law enforcement officials, to solve problems concerning the large number of missing children among migrants in Europe. The recent initiatives to develop cooperation with EU policy makers have included several conferences and a photo exhibition organized in the European Parliament during the week of International Children's Missing Day [15].

Another example of cooperation of NGOs with authorities in other countries can be found in Turkey, where, in cooperation with the British Embassy, a local NGO «The Human Resources Development Fund», has implemented a training program to combat trafficking in human beings for its counterparts in the provinces of Turkey, that is the most dangerous because of the influx of Syrian refugees. The main objective of this training is to transfer relevant experience in combating trafficking in human beings to local NGOs in order to reach refugee populations, particularly women and children, in order to reduce the risk of trafficking in human beings [11].

Conclusions. Thus, by analyzing the cooperation of NGOs with some international actors, we can conclude that the interaction of non-governmental organizations with other international actors, in order to solve global problems of civil society, provides many options for coordination of their mutual efforts, in particular:

- holding joint forums, conferences, seminars;

- providing grants and awards to fund targeted NGOs' projects in specific areas of civil society;

- participation as observers in sessions and meetings of intergovernmental actors;

- financing of innovative and pilot NGOs' projects both at the national and regional level.

Today, NGOs have a tremendous impact on the actions and development of both governmental and intergovernmental actors, as they catalyze global change in civilization, while expressing the views of world civil society. Collaboration with NGOs enables IGOs to form strategic partnerships; to increase the efficiency and effectiveness of organizations' programs and activities; to increase the impact of programs and activities of organizations at global, regional and national levels; to increase the efficiency of implementing the normative acts of organizations and monitoring their application; to expand the scope of its activities and to cover all sections of society; to increase the effectiveness of IGOs activities as a whole. 


\section{REFERENCES}

1. Naumov A. (2013). International non-governmental organizations and global governance issues. Public administration. Electronic bulletin. Release № 39. P. 49-76

2. International Organizations: Educ. tool. / edited by Yu. Kozak, V. Kovalevsky, Z. Kutayni. Kyiv: Center for Educational Literature, 2007. P. 341

3. Department of Global Communications. Partnerships (UN) URL: https://www.un.org/ru/sections/departments/department-global-communications/building-partnerships/index.html

4. Ukrainian Center for Cultural Research. Structure of UNESCO. URL: http://uccs.org.ua/sklad-iunesko/

5. List of NGOs in official partnership with UNESCO within the framework of the Directives concerning UNESCO's partnership with non-governmental organizations (36C / Res. 108) URL: https://en.unesco.org/sites/default/files/list_of_ngos_in_official_partner-

ship_with_unesco_-_liste_des_ong_en_partenariat_officiel_avec_lunesco_-_06.2019.pdf

6. Three projects in Asia advance the rights of vulnerable youth (UNITED NATIONS DEMOCRACY FUND). URL: https://www.un.org/democracyfund/news/three-projects-asiaadvance-rights-vulnerable-youth

7. Partnerships: at the very heart of our work (UNICEF). URL: https://www.unicef.org/eca/what-we-do/our-partners
8. Civil Society Partners. URL: https://childrenandarmedconflict.un.org/ru/civil-society-partners/

9. Youth Support in Europe. European Youth Foundation. URL: https://rm.coe.int/CoERMPublicCommonSearchServices/DisplayDCTMContent?documentId=0900001680471 c01

10. European Youth Foundation. URL:https://www.coe.int/en/web/european-youth-foundation/what-we-support

11. The Critical Role of Civil Society in Combating Trafficking in Human Beings. Network meeting of lawyers, conclusions and suggestions for future action, 2016. Strasbourg. URL: https://www.osce.org/ru/secretariat/411182?download=true

12. THE NATIONAL ENDOWMENT for DEMOCRACY. URL: https://www.ned.org/about/

13. USAID and the AGA KHAN FOUNDATION WORK to INCREASE the Impact of Local Organizations in CENTRAL ASIA. URL: https://www.usaid.gov/news-information/pressreleases/dec-2-2019-usaid-and-aga-khan-foundation-work-increase-impact-local-organizations

14. Advice on Individual Rights in Europe. URL: http://www.airecentre.org/pages/humanrights-litigation-human-trafficking-37.html

15. Missing Children Publication Hub. URL: http://missingchildreneurope.eu/catalog/categoryid/20 